\title{
FACTORS AFFECTING PATIENT COMPLIANCE TO THE NATIONAL HEALTH INSURANCE REFERAL SYSTEM IN MEDAN, NORTH SUMATERA
}

\author{
Suryati Sinurat'), Ida Yustina ${ }^{2)}$, Destanul Aulia ${ }^{2)}$ \\ 1)Study Program in Hospital Management, \\ Faculty of Public Health, Universitas Sumatera Utara \\ 2)Department of Administration and Health Policy, \\ Faculty of Public Health, Universitas Sumatera Utara
}

\begin{abstract}
Background: Referal system is a critical element of the national health insurance $(\mathrm{JKN})$ scheme that is managed by the Managing Body of Social Insurance (BPJS). An effective referral system ensures a close relationship between all levels of the health system and helps to ensure people receive the best possible care closest to home. It also assists in making cost-effective use of hospitals and primary health care services. Support to health centres and outreach services by experienced staff from the hospital or district health office helps build capacity and enhance access to better quality care. To date, however, the referal system had not been implemented as expected. This study aimed to analyze factors affecting patient compliance with the national health insurance referal system at Royal Prima Hospital, Medan, North Sumatera.

Subjects and Methods: This was a cross sectional study conducted at Royal Prima Hospital, Medan, North Sumatera. A sample of 164 BPJS patients were selected for this study. The dependent variable was compliance with the referal system of JKN. The independent variables was accomodation. The data were collected by questionnaire and analyzed by a logistic regression model.

Results: Patient compliance with the referal system of JKN was associated with accomodation cost incurred by the patient and the attending family member.

Conclusion: Patient compliance with the referal system of $\mathrm{JKN}$ is associated with accomodation cost incurred by the patient and the attending family member.
\end{abstract}

Keywords: referal system, primary care, hospital, compliance, patients, national health insurance

\section{Correspondence:}

Suryati Sinurat. Study Program in Hospital Management, Faculty of Public Health, Universitas Sumatera Utara, Medan, North Sumatera.

Email: angatashutagalung@yahoo.com. Mobile:+62 812-6313-1982.

The 4th International Conference on Public Health

Best Western Premier Hotel, Solo, Indonesia, August 29-30, 2018 | 233 https://doi.org/10.26911/theicph.2018.04.01 